\title{
Application of Balanced Scorecard in Performance Management Innovation of Agricultural Enterprises
}

\author{
Changzhi Li, Zhongcheng Pan, Jing Weng, Pumin Li
}

Shaanxi Microbe Biological Technology Co., Ltd, Weinan 715500, Shaanxi, China.

\begin{abstract}
With the continuous reform of the market economic system, China's agricultural enterprises are facing increasingly fierce market competition. The enterprise scale, talents, innovation ability and advanced technology are the core competitiveness of enterprises for occupying a place in the competitive market. To improve the competitiveness, enterprise performance management is indispensable. The traditional performance management system has been unable to meet the development needs of agricultural enterprises. Because of its comprehensive and objective management characteristics, balanced scorecard has been widely used in many fields. Starting from the overview of balanced scorecard, this paper analyzes the problems faced by agricultural enterprises in performance management, and discusses its application in performance management innovation of agricultural enterprises, aiming to improve the performance management level of agricultural enterprises and promote the long-term development of agricultural industry.

Keywords: Balanced Scorecard; Agricultural Enterprises; Performance Management

The deepening reform of rural economic system has accelerated the process of China's agricultural industrialization. Many agricultural enterprises have realized the separation of ownership and management rights, and have become modern enterprises in the true sense. The organizational structure of enterprises has also undergone great changes. Under this background, agricultural enterprises need to formulate scientific and effective performance management system to promote agricultural enterprises in China sustainable development.
\end{abstract}

\section{Overview of balanced scorecard}

\subsection{The connotation of balanced scorecard}

The balanced scorecard theory was proposed in 1990, and then widely used in global enterprise management, which has achieved remarkable results in enterprise performance management. It is to systematically manage the performance of enterprises through four levels: customer, finance, operation management and learning improvement, so as to systematic manage the enterprise performance and upgrade the effect of enterprise performance management.

\subsection{Four levels of balanced scorecard}

The first is the customer level, which is also the primary index to be included in the construction of the performance evaluation index system in the balanced scorecard, because customer satisfaction is the magic weapon for enterprises to seize market share in the process of business development. Through the index of customer satisfaction, customer profitability, customer retention rate, and new customer growth rate, the quality of enterprise products and services can be directly reflected, Once these index fluctuate, it shows that there is a gap between the expected value of products and customers, adjustment is needed in time.

Secondly, the financial level, which is an essential index in enterprise performance management, can objectively evaluate the operation ability, debt paying ability, development ability and profitability of an enterprise. It can also objectively reflect the completion progress of the financial objectives of the last quarter, which is directly related to the Copyright @ 2020 Changzhi Li et al.

doi: 10.18282/le.v9i7.1522

This is an open-access article distributed under the terms of the Creative Commons Attribution Non-Commercial License

(http://creativecommons.org/licenses/by-nc/4.0/), which permits unrestricted non-commercial use, distribution, and reproduction in any medium, provided the original work is properly cited. 
survival and development of the enterprise. The balanced scorecard can set up operating income, economic value-added, return on assets and other indexes in the financial level can be set up in the balanced scorecard, so as to reflect the value improvement of enterprises.

The third is the operation management level. The balanced scorecard performance management mode focuses on enterprise operation management. On the basis of combing the internal business process of the enterprise, combined with the external customer service process, it improves the internal and external cooperation of the enterprise. From the enterprise innovation link to the after-sales, the problems existing in the enterprise operation and management through the index of some core activities can be seen, and make timely adjustments.

Finally, the learning improvement level. To realize the strategic plan of the enterprise, the learning and growth of all employees is indispensable. The balanced scorecard has paid enough attention to this. Through the index of employee training, employee satisfaction and employee retention rate, it can truly reflect the continuous improvement of employees' ability and provide core competitiveness of talents for the development of enterprises [1].

\section{Dilemma of agricultural enterprises in performance management}

\subsection{Lack of long-term strategic return for the traditional enterprise performance evaluation}

In the current performance management system of agricultural enterprises, most of them still rely on the traditional performance evaluation method with simple operation, that is, directly extract financial data from enterprise financial statements. Through the calculation of various data indexes, the financial performance of agricultural enterprises in the previous stage can be objectively evaluated. However, this kind of evaluation system reflecting the short-term financial performance makes the management of agricultural enterprises prone to the idea of eager for quick success and instant benefit. During their tenure, they only pay attention to the improvement of short-term business performance, and do not consider the investment projects with long-term strategic return, which will make the agricultural enterprises have a good performance in the current period, as the result, the enterprises cannot achieve the long-term development due to lack of the ability of sustainable development.

\subsection{Lack of consideration of equity capital cost for the traditional financial performance evaluation}

The traditional financial performance evaluation of agricultural enterprises has been staying at the level of accounting profit, which only objectively reflects the capital cost of enterprise debt, and lacks the consideration of equity capital cost from the economic profit level. The investors' capital is used free of charge by the traditional financial performance evaluation system and is not included in the cost of capital, which leads to overstating the business performance of enterprises and overestimating the profitability of enterprises, thus misjudging the true value of enterprises [2].

\subsection{Lacking objective and perfect measurement method for traditional enterprise performance evaluation}

In the traditional performance evaluation system, agricultural enterprises focus on financial indexes, and some enterprises even fully rely on them. This kind of neglect of non-financial evaluation indexes is easy to produce opportunistic behavior and damage the long-term interests of enterprises. The emphasis on non-financial indexes has formed a trend in the performance management of agricultural enterprises. However, the subjectivity of measurement methods based on non-financial indicators will lead to the results of performance evaluation not objective enough. Therefore, continuous improvement and optimization of performance evaluation system is the continuous work of agricultural enterprises.

\subsection{Lack of flexible evaluation means for the traditional performance index empowerment}

The current evaluation method of agricultural enterprise performance is a combination of subjective empowerment and fixed weight. Its most prominent problem is that it does not consider the special evaluation needs of agricultural enterprises, which restricts the flexibility of the performance evaluation system to a certain extent, and cannot meet all the needs of enterprises, resulting in the deviation between the evaluation results and the real performance of enterprises. 


\section{Application of balanced scorecard in performance management innovation of agricultural enterprises}

\subsection{Establishing effective performance management communication mechanism}

In order to apply the balanced scorecard to the performance management of agricultural enterprises, and play a certain effect, it is necessary to establish an effective performance management mechanism in agricultural enterprises. Starting from the internal communication of enterprises, the balanced scorecard performance management system should be infiltrated into the internal staff, especially for those employees who are resistant to performance management. The purpose of performance management is not to punish employees, but to promote better cooperation between employees and enterprises, so as to improve the performance of them both. Performance management is more often used to perform monitoring duties, in order to reduce or eliminate the probability of failure. Only when the internal staff of the enterprise reach a consensus to implement it together, can the balanced scorecard performance management play a maximum role in agricultural enterprises.

\subsection{Establishing scientific and standard performance management evaluation system}

In order to fully play the role of balanced scorecard in performance management of agricultural enterprises, it is necessary to establish a scientific and standardized performance management evaluation system, which includes five: plan, implementation, assessment, evaluation and results. In the formulation of performance management plan, the enterprise strategy should be adhered as the guidance, and combine the quantitative and qualitative indexes in the formulation of performance evaluation indexes. After the completion of the balanced scorecard performance management and assessment, the final performance results should be fed back to the enterprises to be evaluated, and the results should be incorporated into the salary structure of enterprise employees, so as to realize the supervision function of the balanced scorecard and working enthusiasm improvement for employees.

\subsection{Establishing clear performance management collaborative framework}

The organizational structure of agricultural enterprises has different management levels in vertical view and operation departments in horizontal view. The intersection is each position, and each functional department constructs the whole agricultural enterprise framework. Facing the different responsibilities of the positions at this level, the performance objectives set by the balanced scorecard should be gradually decomposed by level. In addition to a single performance goal, the balanced scorecard should also formulate the overall strategic framework of agricultural enterprises, use one enterprise general goal to encourage the performance of each functional department, and promote the departments to strengthen collaborative management with balanced development.

\subsection{Strengthening the performance training of enterprise related personnel}

The application of balanced scorecard in the performance management of agricultural enterprises is still in the initial stage, and there will be many problems in the implementation of running in process. After analyzing these problems, it is found that the most important reason is that the managers at all levels of agricultural enterprises do not have a deep understanding of the balanced scorecard performance management mode, and the mastery of management system technology needs to be improved. In view of this, all agricultural enterprises should strengthen the training of relevant personnel, mainly including the training of performance management concept and technology. Only when the enterprise managers have a deep awareness of balanced scorecard performance management and can skillfully and accurately use it, can the management role of balanced scorecard be fully exerted and the agricultural enterprise performance management work be carried out orderly [3].

\section{Conclusion}

To sum up, the balanced scorecard can effectively improve the performance management level of agricultural enterprises, and has a significant positive effect on the development of enterprises. Therefore, in order to fully implement this effective performance management approach, agricultural enterprises should combine their own development situation, make clear the problems that may be encountered in the application process of balanced 
scorecard, and use it scientifically and reasonably, timely and properly, in order to solve the problems, give full play to the balanced scorecard for helping agricultural enterprises to establish a sound performance management system, and providing strong support for the realization of enterprise strategic objectives.

\section{References}

1. Peng H, Gou T, Zhou X. Research on Performance Evaluation of Agricultural Festivals Based on Balanced Scorecard. Hubei Agricultural Science, 2018 (1) :127-130.

2. Dai J, Hu P, Wang X, Zhou C. Discussion on the Role of Balanced Scorecard in Improving Enterprise Performance Management. Financial Supervision, 2020 (4) : 84-87.

3. Zhang X, Wu L. Research on Performance Management Countermeasures of Small and Medium-Sized Enterprises based on Balanced Scorecard . Contemporary Economy, 2019 (9) : 123-125. 